\title{
Potassium nitrate to overcome dormancy of Urochloa humidicola Comum seeds
}

\section{Nitrato de potássio na superação da dormência de sementes de Urochloa humidicola Comum}

\author{
Thaís Soares Pereira ${ }^{1 *}$; Tatiane Sanches Jeromini²; Breno Rosa Neves²; \\ Renato Téo de Barros²; Cibele Chalita Martins ${ }^{3}$
}

\section{Highlights}

Seeds of Urochloa humidicola exhibit a high percentage of dormancy. Immersion of seeds in $\mathrm{KNO}_{3}$ solution overcomes dormancy and promotes germination. $U$. humidicola seeds must be immersed in $4 \%$ solution of $\mathrm{KNO}_{3}$ for $24 \mathrm{~h}$ before sowing.

\begin{abstract}
The main difficulty with propagating Urochloa humidicola Comum is the high percentage of seed dormancy. Thus, the objective of this study was to develop a treatment to overcome seed dormancy and promote seed germination of this species that can be applied at a large scale. This study was conducted in two stages. First, the following treatments were evaluated using one seed lot: control (without treatment), immersion in $\mathrm{H}_{2} \mathrm{SO}_{4}(98 \%, 36 \mathrm{~N})$ for 10 min, moistening the germination substrate with $\mathrm{KNO}_{3}(0.2 \%)$ and immersion in $\mathrm{KNO}_{3}$ at concentrations of $0 \%, 2 \%, 4 \%, 6 \%$, and $8 \%$ for periods of $12,24,36$, and $48 \mathrm{~h}$, followed by drying in the shade. In the second stage, three seed lots were evaluated in all of the aforementioned treatments, except for those of immersion in $0 \% \mathrm{KNO}_{3}$ and of all concentrations for 36 and $48 \mathrm{~h}$. The seeds were evaluated for water content, germination, percentage of abnormal seedlings, dead and dormant seeds, first count, and average germination time. Immersion in the $\mathrm{KNO}_{3}$ solution was efficient in overcoming dormancy and promoting germination. To be used by companies, the immersion of seeds in a $4 \% \mathrm{KNO}_{3}$ solution for 24 $\mathrm{h}$ was the most suitable treatment to overcome dormancy and promote the germination of $U$. humidicola Comum seeds.
\end{abstract}

Key words: Urochloa humidicola. Quicuio grass. Forage. Germination. $\mathrm{KNO}_{3}$. Physiological potential.

1 Trainee, Vale do Paraná S/A Industry, Alcohol and Sugar, Suzanópolis, SP, Brazil. E-mail: thaisoares_13@hotmail.com

2 PhD Students of the Graduate Program in Agronomy, Plant Production, São Paulo State University "Júlio de Mesquita Filho", School of Agrarian and Veterinary Sciences, UNESP/FCAV, Jaboticabal, SP, Brazil. E-mail: tatiane_jeromini@ hotmail.com; br.nevesb@gmail.com; renato.barros@unesp.br

3 Full Professor, UNESP/FCAV, Jaboticabal, SP, Brazil. E-mail: cibele.chalita@unesp.br

* Author for correspondence

Received: June 03, 2020 - Approved: Dec. 03, 2020 


\section{Resumo}

A principal característica que dificulta a utilização das sementes de Urochloa humidicola cv. Comum é a alta porcentagem de dormência. Assim, o objetivo do trabalho foi obter um tratamento para a superação da dormência e promoção da germinação das sementes desta espécie passível de aplicação em grande escala. $\mathrm{O}$ trabalho foi conduzido em duas etapas. Na primeira, foram avaliados em um lote de sementes os seguintes tratamentos: testemunha (sem tratamento), imersão em $\mathrm{H}_{2} \mathrm{SO}_{4}(98 \%, 36 \mathrm{~N})$ por 10 minutos, umedecimento do substrato de germinação com $\mathrm{KNO}_{3}(0,2 \%)$ e imersão em $\mathrm{KNO}_{3}$ nas concentrações de $0,2,4,6$ e $8 \%$ por períodos de 12, 24, 36 e 48 horas, seguida por secagem à sombra. Na segunda etapa, foram avaliados em três lotes de sementes todos os tratamentos supracitados, exceto a imersão em $\mathrm{KNO}_{3}$ $0 \%$ e todas as concentrações nos períodos 36 e 48 horas. As sementes foram avaliadas quanto ao teor de água, germinação, porcentagem de plântulas anormais, sementes mortas e dormentes, primeira contagem e tempo médio de germinação. A imersão em solução de $\mathrm{KNO}_{3}$ é eficiente para a superação da dormência e promoção da germinação. Visando a utilização pelas empresas, a solução de $\mathrm{KNO}_{3} 4 \%$ por 24 horas é o tratamento mais indicado.

Palavras-chave: Urochloa humidicola. Capim quicuio. Forrageira. Germinação. $\mathrm{KNO}_{3}$. Potencial fisiológico.

\section{Introduction}

Urochloa humidicola (Rendle) Morrone \& Zuloaga is an efficient forage which protects against soil against erosion by producing a large number of stolons (Alves et al., 2017). This species has greater tolerance than other $U$. species to acidic, low-fertility, and poorly drained soils, it shows resistance to intense grazing and has a greater capacity for establishment in new areas (Alves et al., 2017; Euclides et al., 2010).

For the formation of pastures, it is necessary to use seeds of high physical and physiological quality. However, the seeds of $U$. humidicola exhibit a high percentage of dormancy (above $40 \%$ ), and this state persists for periods greater than 12 months (Costa, Araújo, \& Villa Bôas, 2011; Libório et al., 2017). In the field, dormancy causes variation in the emergence of seedlings, impairing the establishment of pastures, and favoring the invasion of weeds (L. Martins \& Silva, 2001).
The main strategy adopted by companies to overcome the dormancy of $U$. humidicola seeds in commercial production is storage for years; however, this procedure represents a higher production cost with storage and an obstacle to logistics (Costa et al., 2011). One of the possible causes of dormancy in species of the genus Urochloa is the restriction of gas exchange because of the presence of glume, palea, and lemma (Binotti, Sueda, Cardoso, Haga, \&Nogueira, 2014). These structures can be removed by scarification with sulfuric acid $\left(\mathrm{H}_{2} \mathrm{SO}_{4}\right)$ (Ministério da Agricultura, Pecuária e Abastecimento [MAPA], 2009). However, some authors have found that this treatment has a detrimental effect on seed viability, in addition to presenting risks to workers and the environment (Verzignassi et al., 2013; Moreira, 2014).

This dormancy can also be overcome by the application of substances that contain radicals, such as $\mathrm{NO}^{-3}$ (nitrate) or $\mathrm{NO}^{-2}$ (nitrite), because they have an oxidizing action and 
act on physiological processes, causing the biosynthesis of new compounds and starting the germination process of seeds (Cardoso, Sá, Haga, Binotti, \& Costa, 2015) by activating an anaerobic pathway, the pentose-phosphate pathway, which initiates metabolic reactions in the Krebs cycle. Consequently, this provides the energy supply for the germination process (N. M. Carvalho \& Nakagawa, 2012). Sowing on a substrate moistened with a solution $(0.2 \%)$ of potassium nitrate $\left(\mathrm{KNO}_{3}\right)$ is a method recognized for its efficiency in overcoming the dormancy of several species of forage grasses. However, its application is restricted to the installation of tests under laboratory conditions, because it is not feasible under field conditions (C. C. Martins \& Silva, 1998; L. Martins \& Silva, 2001; MAPA, 2009).

To determine the favorable effects of $\mathrm{KNO}_{3}$ in overcoming dormancy and promoting germination, some researchers have immersed grass seeds in this solution, dried them, and sown them later, thereby obtaining promising results (Binotti et al., 2014; Libório et al., 2017; C. C. Martins, Velini, \& Martins, 1997). However, there are still uncertainties regarding the best concentration of the $\mathrm{KNO}_{3}$ solution and the immersion time for each species and cultivar. Thus, the objective of this study was to ascertain a treatment to overcome dormancy and promote germination of $U$. humidicola Comum that can be applied by companies.

\section{Material and Methods}

The research was conducted with three seed lots of $U$. humidicola Comum in the Seed Analysis Laboratory of the Department of Plant Production of the University of Agricultural and Veterinary Sciences of UNESP, Jaboticabal
Campus. Seeds were subjected to a pneumatic blower for cleaning and subsequently to manual picking to obtain a portion of pure seeds for the application of treatments from which to conduct the performance analysis.

The study was conducted in two stages. First, one of the lots was submitted to the following treatments: ST, absolute control wherein the seeds had no treatment; $\mathrm{T} \mathrm{KNO}_{3}$ sowing seeds in a substrate moistened with $0.2 \% \mathrm{KNO}_{3}$ solution; $\mathrm{T}_{2} \mathrm{SO}_{4^{\prime}}$ the immersion of seeds in $\mathrm{H}_{2} \mathrm{SO}_{4}(98 \%, 36 \mathrm{~N})$ for $10 \mathrm{~min}$, followed by washing in running water for $3 \mathrm{~min}$, removing surface moisture with absorbent paper, and drying in the shade on paper towels sheets at $25^{\circ} \mathrm{C}$ for $24 \mathrm{~h}$; immersion treatments in KNO3 solution at concentrations $0 \%$ (distilled water), $2 \%, 4 \%, 6 \%$, and $8 \%$ for periods of $12,24,36$, and $48 \mathrm{~h}$, followed by drying in the shade on paper towels at $25^{\circ} \mathrm{C}$ for $24 \mathrm{~h}$ (L. Martins \& Silva, 2001; Torres et al., 2016; Verzignassi et al., 2013). The immersion treatments that proved to be more efficient in overcoming dormancy and promoting seed germination were applied to three seed lots, together with the controls, in the second stage of the experiment.

For immersion in $\mathrm{KNO}_{3^{\prime}} 2 \mathrm{~g}$ of seeds were used in $40 \mathrm{~mL}$ of the solution inside a transparent $180 \mathrm{ml}$ plastic cup, which was maintained at $25{ }^{\circ} \mathrm{C}$ for the pre-established periods. After the immersion period, seeds were removed from the solution and placed on paper towels to dry in the shade at $25^{\circ} \mathrm{C}$ for $24 \mathrm{~h}$. The seeds were evaluated using the following tests and analyses.

Water content was determined using the oven drying method at $105^{\circ} \mathrm{C}$ immediately after the application of the treatments and before the germination test with two subsamples of $0.5 \mathrm{~g}$ of seeds at $105 \pm 3^{\circ} \mathrm{C}$ for 
$24 \mathrm{~h}$ (MAPA, 2009). Germination was conducted using four subsamples of 50 seeds sown on two sheets of germination test paper moistened with 2.5 times the weight of the paper placed in transparent plastic boxes with a lid $(11.0 \times 11.0$ $\times 3.5 \mathrm{~cm}$ ) and maintained under an alternating temperature of $20-35^{\circ} \mathrm{C}$ and photoperiod of 8 h (MAPA, 2009). Seedlings were counted daily after the beginning of germination until the $21^{\text {st }}$ day after sowing. The percentage of normal and abnormal seedlings were calculated.

Tetrazolium was used for the identification and counting of dormant and dead seeds. The remaining seeds in the germination test were cut in half in the longitudinal direction, and one of the halves was immersed in a solution of $0.1 \% 2,3,5$ triphenyl tetrazolium chloride at $37^{\circ} \mathrm{C}$ for $3 \mathrm{~h}$. After this period, the embryos were evaluated using a magnifier (10× magnification) with LED lighting, and the results were expressed as a percentage (MAPA, 2009).

The first germination count was conducted together with the germination test by counting the normal seedlings present on the fifth day after sowing, and the results were presented as a percentage (Silva, Martins, Cruz, Jeromini, \& Bruno, 2017). Average germination time (AGT) was performed with the germination test and was conducted by applying a previously described method (D. B. Carvalho \& Carvalho, 2009).

The data obtained were analyzed using a completely randomized experimental design (CRD) in a $5 \times 4+3$ factorial scheme (concentrations of $\mathrm{KNO}_{3} \times$ periods + controls) with four replications in the first stage of the research, and $11 \times 3$ (treatments $\times$ lots) with four repetitions in the second stage. For the factors germination, abnormal seedlings, dead and dormant seeds, and the first germination count, data were transformed using arcsine $(x / 100)^{1 / 2}$ to meet the assumptions of the tests of normality and homogeneity of variance using the Shapiro-Wilk test. The treatment means were subjected to an analysis of variance using the $\mathrm{F}$ test and compared by the Tukey test at 5\% probability using Agroestat software (Barbosa \& Maldonado, 2015). The averages presented in the tables are the percentages of the original data. Data regarding the water content of the seeds were not evaluated statistically.

\section{Results and Discussion}

\section{First stage of the research}

The water content of the seeds obtained immediately after the application of the treatments ranged from $13.2 \%$ (control) to $54.4 \%$. In immersion treatments, the lower the concentration of the solution, the greater the hydration of the seeds. For concentrations of $0 \%, 2 \%, 4 \%, 6 \%$, and $8 \% \mathrm{KNO}_{3}$, the average values of water content were $50.8 \%, 47.0 \%$, $46.0 \%$, $45.3 \%$, and $40.9 \%$, respectively. Scarification in sulfuric acid resulted in a water content of $24.9 \%$ in the seeds.

The presence of salts reduced the water potential of the solution by restricting water uptake by the seed (Lopes \& Macedo, 2008). Thus, with the increase in the concentration of $\mathrm{KNO}_{3}$ in the solution, there was an increase in osmotic pressure and less water absorption by the seeds (Dias et al., 2016). The increase in hydration observed in $\mathrm{H}_{2} \mathrm{SO}_{4}$ scarified seeds occurred because of the rupture of the physical barrier caused by acid on the seed lining structures, favoring the absorption of water after rinsing (Tomaz, Martins, Silva, \& 
Vieira, 2016). Although there was substantial variation in the water content of the seeds immediately after the treatments, drying for $24 \mathrm{~h}$ before the installation of the quality tests allowed for uniformity of the values, which were between $7.5 \%$ and $8.9 \%$. Thus, the evaluations could be conducted without interference from the hydration levels of the seeds (MAPA, 2009; Melo, Martins, Silva, Boneti, \& Vieira, 2016; Steiner, Oliveira, Martins, \& Cruz, 2011).

The analysis of variance showed significant effect of both the concentration and the period of immersion in the solution for dormant seeds (Table 1). For germination, dead seeds and AGT the interaction between concentration and immersion period was statistically significant (Table 2), and for abnormal seedlings and the first count test (Table 3), only the isolated effect of the concentration of the $\mathrm{KNO}_{3}$ solution was significant. The high coefficient of variation could be explained by the variability of the treatments tested and the differences in the quality of the lots.

The effect of seed immersion treatments in $\mathrm{KNO}_{3}$ solution on dormancy is presented in Table 1. It was observed that, when compared to water immersion ( $\left.\mathrm{KNO}_{3} 0 \%\right)$, KNO3 solutions at all concentrations reduced dormancy between 92\% and 96\% (38.4\% and $40.2 \%$, respectively), and immersion for periods greater than 24 hours gave the best results to overcome dormancy with an average percentage of $9.2 \%$.

For germination, seed immersion in $\mathrm{KNO}_{3}$ for 12,24 , and $36 \mathrm{~h}$ was the most favorable for all concentrations equal to or greater than $2 \%$ (Table 2 ), with values between $59 \%$ and $72 \%$. In contrast, in a previous study (Libório et al., 2017) seed immersion treatment of $U$. humidicola BRS Tupi in $\mathrm{KNO}_{3}$ solution at concentrations below $1 \%$ did not yield promising results.

The positive results of treatments with $\mathrm{KNO}_{3}$ suggest that a possible cause of the dormancy in this species is the restriction of gas exchange. After being absorbed, nitrate acts in the formation of NADP+, stimulating respiration through the pentose-phosphate pathway, which does not require oxygen; thus, dormancy is overcome by energy production to begin the germination process (Marcos, 2015). 
Table 1

Dormant seeds (D) of Urochloa humidicola Comum as a function of KNO3 solution immersion treatments applied in the first stage of the research.

\begin{tabular}{|cc|}
\hline Concentration $\mathrm{KNO}_{3}$ & $\mathrm{D}(\%)$ \\
\hline $0 \%$ & $41,8 \mathrm{~b}$ \\
$2 \%$ & $3,4 \mathrm{a}$ \\
$4 \%$ & $2,9 \mathrm{a}$ \\
\hline $6 \%$ & $1,6 \mathrm{a}$ \\
\hline $8 \%$ & $1,8 \mathrm{a}$ \\
$\mathrm{MS}$ & $3665,20^{* *}$ \\
\hline $\mathrm{CV}(\%)$ & 39,05 \\
\hline Period & $\mathrm{D}(\%)$ \\
\hline $12 \mathrm{~h}$ & $13,7 \mathrm{~b}$ \\
\hline $24 \mathrm{~h}$ & $9,2 \mathrm{a}$ \\
$36 \mathrm{~h}$ & $8,9 \mathrm{a}$ \\
$48 \mathrm{~h}$ & $9,5 \mathrm{a}$ \\
$\mathrm{MS}$ & $221,37^{* *}$ \\
$\mathrm{CV}(\%)$ & 39,05 \\
\hline
\end{tabular}

Means followed by the same lowercase letter in a column for each parameter do not differ statistically by the Tukey test $(P>0.05)$. Data were transformed by arcsine $(x / 100)^{1 / 2}$ and original means are presented.

MS: Mean square; CV: Coefficient of variation; ${ }^{*}$,*: indicate significant difference by the $\mathrm{F}$ test $(P \leq 0.05$ and $P \leq 0.01$, respectively). 


\section{Table 2}

Germination (G), dead seeds (M), and average germination time (AGT) of seeds of Urochloa humidicola Comum as a function of $\mathrm{KNO} 3$ solution immersion treatments applied in the first stage of the research

\begin{tabular}{|c|c|c|c|c|c|}
\hline & $\mathrm{KNO}_{2}$ & \multicolumn{4}{|c|}{ Period } \\
\hline & Concentration & $12 \mathrm{~h}$ & $24 \mathrm{~h}$ & $36 \mathrm{~h}$ & $48 h$ \\
\hline \multirow{5}{*}{$\begin{array}{l}\mathrm{G}^{1} \\
(\%)\end{array}$} & $0 \%$ & $23,5 \mathrm{bAB}$ & $14,3 \mathrm{bB}$ & 34,8 bA & $24,0 \mathrm{cAB}$ \\
\hline & $2 \%$ & 63,3 aA & 66,0 aA & 69,8 aA & 61,0 aA \\
\hline & $4 \%$ & $72,0 \mathrm{aA}$ & $66,0 \mathrm{aAB}$ & $65,3 \mathrm{aAB}$ & $49,8 \mathrm{abB}$ \\
\hline & $6 \%$ & $70,8 \mathrm{aA}$ & 69,3 aA & 58,3 aA & $40,5 \mathrm{bB}$ \\
\hline & $8 \%$ & 68,8 aA & $66,3 \mathrm{aAB}$ & 59,3 aAB & $51,5 \mathrm{abB}$ \\
\hline MS & & \multicolumn{4}{|c|}{$84,24^{* *}$} \\
\hline CV (\%) & & \multicolumn{4}{|c|}{11,48} \\
\hline \multirow{5}{*}{$\begin{array}{l}M^{1} \\
(\%)\end{array}$} & $0 \%$ & $27,3 \mathrm{aAB}$ & $36,8 \mathrm{aB}$ & 20,0 aA & 30,5 aAB \\
\hline & $2 \%$ & 23,5 aA & 27,5 aA & $28,3 a b A$ & 34,0 aA \\
\hline & $4 \%$ & 20,0 aA & $32,0 \mathrm{aAB}$ & $33,3 \mathrm{abB}$ & $45,3 \mathrm{abB}$ \\
\hline & $6 \%$ & $18,3 \mathrm{aA}$ & $29,8 \mathrm{aAB}$ & 39,5 bB & $57,0 \mathrm{bC}$ \\
\hline & $8 \%$ & 27,8 aA & 28,8 aA & $34,5 \mathrm{bAB}$ & $45,0 \mathrm{abB}$ \\
\hline MS & & \multicolumn{4}{|c|}{$76,69^{* *}$} \\
\hline CV (\%) & & \multicolumn{4}{|c|}{14,27} \\
\hline \multirow{5}{*}{$\begin{array}{l}\text { AGT } \\
\text { (days) }\end{array}$} & $0 \%$ & $10 \mathrm{bAB}$ & $11 \mathrm{bB}$ & $9 \mathrm{aA}$ & $10 \mathrm{bAB}$ \\
\hline & $2 \%$ & $8 \mathrm{aA}$ & $7 \mathrm{aA}$ & $7 \mathrm{aA}$ & $8 \mathrm{aA}$ \\
\hline & $4 \%$ & $7 \mathrm{aA}$ & $8 \mathrm{aAB}$ & $8 \mathrm{aAB}$ & $9 \mathrm{abB}$ \\
\hline & $6 \%$ & $9 \mathrm{abAB}$ & $8 \mathrm{aA}$ & $8 \mathrm{aA}$ & $10 \mathrm{bB}$ \\
\hline & $8 \%$ & $8 \mathrm{aA}$ & $8 \mathrm{aA}$ & $9 \mathrm{aAB}$ & $11 \mathrm{bB}$ \\
\hline MS & & \multicolumn{4}{|c|}{$3,33^{* *}$} \\
\hline CV (\%) & & \multicolumn{4}{|c|}{11,88} \\
\hline
\end{tabular}

Means followed by the same lowercase letter in a column and uppercase in each row for each parameter do not differ statistically from each other by the Tukey test $(P>0.05)$.

$1:$ Data transformed into the arcsine of the square root of $x / 100$ and original means are presented.

MS: Mean square; CV: Coefficient of variation; *, **: indicate significant difference by the $\mathrm{F}$ test $(P \leq 0.05$ and $P \leq 0.01$, respectively). 
Table 3

Abnormal seedlings (A) and first count of germination (FC) of seeds of Urochloa humidicola Comum as a function of $\mathrm{KNO} 3$ solution immersion treatments applied in the first stage of the research.

\begin{tabular}{|ccc|} 
Concentration & $\mathrm{A}$ & $\mathrm{FC}$ \\
& $\mathrm{KNO}_{3}$ & \multicolumn{1}{c|}{$1,3 \mathrm{~b}$} \\
\hline$\%$ & $5,4 \mathrm{~b}$ & $12,0 \mathrm{a}$ \\
$4 \%$ & $3,3 \mathrm{ab}$ & $9,1 \mathrm{ab}$ \\
$6 \%$ & $1,3 \mathrm{a}$ & $5,0 \mathrm{ab}$ \\
$8 \%$ & $2,5 \mathrm{ab}$ & $2,8 \mathrm{~b}$ \\
$\mathrm{MS}$ & $2,8 \mathrm{ab}$ & $492,69^{* *}$ \\
$\mathrm{CV}(\%)$ & $100,63^{*}$ & 110,78 \\
\hline
\end{tabular}

Means followed by the same lowercase letter in a column do not differ statistically from each other by the Tukey test $(P$ $>0.05)$. Data transformed by arcsine $(x / 100)^{1 / 2}$ and the original means are presented.

MS: Mean square; CV: Coefficient of variation; * ${ }^{* *}$ : indicate significant difference by the $\mathrm{F}$ test $(P \leq 0.05$ and $P \leq 0.01$, respectively).

The percentage of germinated and dead seeds after water immersion $\left(\mathrm{KNO}_{3} 0 \%\right)$ for the different periods showed fluctuations in the values. Because the seeds of this species are not restricted from water absorption (Libório, Verzignassi, Fernandes, \& Lima, 2018), more physiological studies are necessary to better explain the oscillation of the effect of the periods of immersion at this concentration. This effect was also observed in the AGT. For the $\mathrm{KNO}_{3}$ solutions, at all concentrations, the seed immersion periods 12 and $24 \mathrm{~h}$ were least harmful. Higher seed mortality was observed with immersion times longer than $36 \mathrm{~h}$ and at concentrations above 4\% (Table 2).

The immersion of the seeds in $\mathrm{KNO} 3$ solution at concentrations higher than $2 \%$ between 12 and $36 \mathrm{~h}$ reduced the AGT. After these treatments, the seeds took 7 and 9 days to germinate, whereas seeds immersed for 48 $\mathrm{h}$ required up to 11 days to germinate.
Based on data from dead seeds and AGT, there was a deleterious effect on seed quality, the higher the concentration and the longer the period of immersion in the $\mathrm{KNO}_{3}$ solution. This fact can be attributed to the phytotoxic effect that salts can have on seeds (Schossler, Machado, Zuffo, Andrade, \& Piauilino, 2012). In addition to influencing water absorption by seeds, ions can be assimilated and accumulated in the protoplasm of cells, causing the destruction of enzymes and membranes, which can damage the embryos (Betoni, Scalon, \& Mussury, 2011; Oliveira, Matias, Silva, Ribeiro, \& Dantas, 2014). Additionally, seed treatments conducted for shorter periods have positive economic implications for producing companies, because they allow a reduction in the time needed for treatment, increasing the yield of the production system and improving the processing, commercialization, and distribution of the seeds (Tomaz et al., 2016). 
The immersion of $U$. humidicola seeds in water $\left(\mathrm{KNO}_{3} \mathrm{0 \%}\right)$ resulted in a higher rate of abnormal seedlings and lower germination speed in the first count test (Table 3). However, for both tests, the treatments that exceeded immersion in water were only $\mathrm{KNO}_{3}$ at $4 \%$ and $2 \%$. The deleterious effect of immersion in water on these variables may have been caused by hypoxia, which compromises cell metabolism and results in loss of the physiological potential and viability of the seeds (Gazola, Zucareli, \& Camargo, 2014).
The seeds without treatment had the highest percentage of dormancy (Table 4). Sowing in a substrate moistened with $\mathrm{KNO}_{3}$ and the scarification of the seeds with $\mathrm{H}_{2} \mathrm{SO}_{4}$ were equally efficient in overcoming dormancy. However, scarification with $\mathrm{H}_{2} \mathrm{SO}_{4}$ caused the death of the seeds, and the breakage of dormancy was not reversed with an increase in the production of normal seedlings. Therefore, seeds placed in substrate moistened with $\mathrm{KNO}_{3}$ to germinate exhibited the highest germination percentages.

\section{Table 4}

Dormant seeds (D), dead seeds (M), germination (G), abnormal seedlings (A), first count (FC), and average germination time (AGT) of seeds of Urochloa humidicola Comum of controls without treatments (ST), substrate moistened with $0.2 \% \mathrm{KNO}_{3}\left(\mathrm{~T} \mathrm{KNO}_{3}\right)$ and scarification of the seeds with $\mathrm{H}_{2} \mathrm{SO}_{4}\left(\mathrm{~T} \mathrm{H}_{2} \mathrm{SO}_{4}\right)$.

\begin{tabular}{ccccccc|} 
Controls & $\mathrm{D}^{1}$ & $\mathrm{M}^{1}$ & $\mathrm{G}^{1}$ & $\mathrm{~A}^{1}$ & $\mathrm{FC}^{1}$ & $\begin{array}{c}\text { AGT } \\
\text { (days) }\end{array}$ \\
\hline $\mathrm{ST}$ & $51,8 \mathrm{~b}$ & $19,3 \mathrm{a}$ & $26,0 \mathrm{c}$ & $3,0 \mathrm{a}$ & $0,0 \mathrm{a}$ & $11,0 \mathrm{~b}$ \\
$\mathrm{~T} \mathrm{KNO}_{3}$ & $6,0 \mathrm{a}$ & $14,0 \mathrm{a}$ & $75,0 \mathrm{a}$ & $4,5 \mathrm{a}$ & $4,5 \mathrm{a}$ & $10,0 \mathrm{ab}$ \\
$\mathrm{TH}_{2} \mathrm{SO}_{4}$ & $3,0 \mathrm{a}$ & $36,0 \mathrm{~b}$ & $54,0 \mathrm{~b}$ & $7,0 \mathrm{a}$ & $1,5 \mathrm{a}$ & $8,5 \mathrm{a}$ \\
$\mathrm{MS}$ & $1576,15^{* *}$ & $270,31^{* *}$ & $889,02^{* *}$ & $28,66^{\mathrm{NS}}$ & $43,61^{\mathrm{NS}}$ & $6,33^{* *}$ \\
$\mathrm{CV}(\%)$ & 39,05 & 14,27 & 11,48 & 62,44 & 110,78 & 11,88 \\
\hline
\end{tabular}

Means followed by the same lowercase letter in a column do not differ statistically from each other by the Tukey test (P $>0.05) .{ }^{1}$ : Data are transformed by arcsine $(x / 100)^{1 / 2}$ and original means are presented.

MS: Mean square; CV: Coefficient of variation; ${ }^{*}$, **: indicate significant difference by the $\mathrm{F}$ test $(P \leq 0.05$ and $P \leq 0.01$,

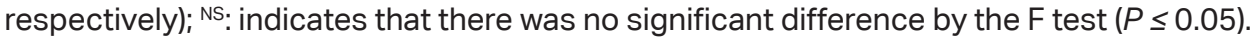

Regarding the germination speed, the seeds without treatment showed the highest AGT, with a higher value than those scarified with $\mathrm{H}_{2} \mathrm{SO}_{4}$. However, the average times of these treatments did not differ from that obtained for seeds germinated in substrate moistened with $\mathrm{KNO}_{3}(0.2 \%)$.

\section{Second stage of the research}

Based on the results of the first stage, treatments with concentrations between $2 \%$ and $8 \%$ and immersion periods of 12 and $24 \mathrm{~h}$ were those with the highest germination and the lowest percentage of dead and dormant seeds. Therefore, these were selected for replication in the three seed lots of $U$. humidicola along with the three control treatments. 
Similar to that observed in the firststage, the water content of the seeds immediately after chemical scarification and immersion in $\mathrm{KNO}_{3}$ solution was higher. This occurred independently of the lot, the concentration of $\mathrm{KNO}_{3}$, and the time of immersion in the solution because of the contact of the seeds with the water during these procedures. However, after the drying period, seeds showed water contents between $7.1 \%$ and $9.0 \%$. Thus, the results of physiological seed evaluations were free from interference caused by differences in water content (Araújo, Zonta, Araújo, Herbele, \& Zonta, 2011).

The percentage of abnormal seedlings showed a significant effect only by treatments, and germination and AGT showed significant differences for the isolated effect of both treatments and lot (Table 5). The lots used in this study showed different germination and vigor values. Based on the results of germination and AGT, lots 1 and 3 responded better than did lot 2.

\section{Table 6}

First count of germination (FC) of Urochloa humidicola Comum as a function of the lots and treatments applied in the second stage of the research

\begin{tabular}{|c|c|c|c|c|}
\hline & & $\mathrm{G}^{1}$ & $A^{1}$ & \multirow{2}{*}{$\begin{array}{c}\text { AGT } \\
\text { (days) }\end{array}$} \\
\hline & & \multicolumn{2}{|c|}{------\%------ } & \\
\hline \multirow{3}{*}{ Lots } & Lot 1 & $61,6 \mathrm{a}$ & $8,95 a$ & $7,4 a$ \\
\hline & Lot 2 & $50,7 \mathrm{~b}$ & $11,27 a$ & $10,0 \mathrm{c}$ \\
\hline & Lot 3 & $63,4 a$ & $9,43 a$ & $8,5 b$ \\
\hline MS & & $754,16^{* *}$ & $66,19 \mathrm{NS}$ & $70,69 * *$ \\
\hline CV (\%) & & 9,10 & 47,92 & 13,29 \\
\hline \multirow{11}{*}{ Treatments } & ST & $23,8 d$ & $4,7 \mathrm{abc}$ & $11 \mathrm{c}$ \\
\hline & T KNO3 & $69,8 \mathrm{a}$ & $4,2 a b c$ & $10 \mathrm{bc}$ \\
\hline & TH2SO4 & $50,2 \mathrm{c}$ & $6,0 \mathrm{bc}$ & $9 a b$ \\
\hline & KNO3 2\%12h & 59,6 bc & $6,8 \mathrm{c}$ & $8 a$ \\
\hline & KNO3 2\%24h & $62,3 a b$ & $2,8 a b$ & $7 a$ \\
\hline & KNO3 4\%12h & $66,0 a b$ & $2,5 \mathrm{a}$ & $8 a$ \\
\hline & KNO3 4\%24h & $64,9 a b$ & $2,3 a$ & $8 a$ \\
\hline & KNO3 6\%12h & $64,9 a b$ & $3,2 a b c$ & $9 a b$ \\
\hline & KNO3 6\%24h & $61,3 a b$ & $3,0 a b c$ & $8 a$ \\
\hline & KNO3 8\%12h & $65,2 a b$ & $2,3 a$ & $9 a b$ \\
\hline & KNO3 8\%24h & $56,3 \mathrm{bc}$ & $3,7 \mathrm{abc}$ & $8 a$ \\
\hline MS & & $709,80^{* *}$ & $83,29^{* *}$ & $12,27^{* *}$ \\
\hline CV (\%) & & 9,10 & 47,92 & 13,29 \\
\hline
\end{tabular}

ST: control without treatment; $\mathrm{T} \mathrm{KNO}_{3}$ : control of moistening of the substrate with $\mathrm{KNO}_{3}(0.2 \%)$; $\mathrm{T} \mathrm{H}_{2} \mathrm{SO}_{4}$ : control with scarification by $\mathrm{H}_{2} \mathrm{SO}_{4}$.

Means followed by the same lowercase letter in a column for each parameter do not differ statistically from each other by the Tukey test $(P>0.05)$.

1: Data transformed by arcsine $(x / 100)^{1 / 2}$ and the original means are presented.

MS: Mean square; CV: Coefficient of variation; * **: indicate significant difference by the $\mathrm{F}$ test $(P \leq 0.05$ and $P \leq 0.01$,

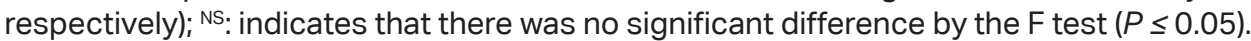


All methods of overcoming dormancy were superior to the control without treatment for germination. However, when comparing with the control treatment, the moistening of the substrate with $\mathrm{KNO}_{3}$ was superior to scarification with $\mathrm{H}_{2} \mathrm{SO}_{4}$. Although $\mathrm{H}_{2} \mathrm{SO}_{4}$ scarification was efficient in overcoming seed dormancy, it did not increase the production of normal seedlings (Table 5). These results were similar to those observed in a previous study with the same species (Torres et al., 2016) and to those obtained in the first stage of the research (Table 2 ).

The treatments that provided greater germination were those wherein seeds were sown in a substrate moistened with $\mathrm{KNO}_{3}$ $(0.2 \%)$ and immersed in $\mathrm{KNO}_{3}$ at $4 \%, 6 \%$, and $8 \%$ for $12 \mathrm{~h}$ and $2 \%, 4 \%$, and $6 \%$ for 24 h (Table 5). Seed scarification with $\mathrm{H}_{2} \mathrm{SO}_{4}$ and sowing on a substrate moistened with $\mathrm{KNO}_{3}$ solution $(0.2 \%)$ are methods recognized for their efficiency in overcoming the dormancy of several species, including forage grasses
(MAPA, 2009; Mendonça, Martins, Martins, \& Lopes, 2015).

The treatment that caused the largest formation of abnormal seedlings was the immersion of the seeds in a $2 \% \mathrm{KNO}_{3}$ solution for $12 \mathrm{~h}$. However, this result did not differ from those obtained in other treatments, such as the three controls and the immersion of the seeds in $4 \%, 6 \%$, and $8 \% \mathrm{KNO}_{3}$ for $24 \mathrm{~h}$ and $6 \%$ for $12 \mathrm{~h}$.

The effects of lots and treatments on the first count of germination are presented in Table 6. Similar to the first stage of research, the variability in the treatments tested and the difference in the quality of lots caused a high coefficient of variation. For lot 1, a greater result was obtained with the scarification of seeds with $\mathrm{H}_{2} \mathrm{SO}_{4}$, and for lot 2, there was no difference between the treatments. In lot 3, the immersion of seeds in $2 \%$ and $4 \% \mathrm{KNO}_{3}$ for $12 \mathrm{~h}$ provided superior results compared to that of the control without treatment. 


\section{Table 6}

First count of germination (FC) of Urochloa humidicola Comum as a function of the lots and treatments applied in the second stage of the research.

\begin{tabular}{|c|c|c|c|}
\hline \multirow[t]{2}{*}{ Treatments } & \multicolumn{3}{|c|}{$\begin{array}{l}\text { FC } \\
\text { (\%) }\end{array}$} \\
\hline & Lot 1 & Lot 2 & Lot 3 \\
\hline ST & $3,5 \mathrm{bA}$ & 0,0 aA & $0,0 \mathrm{bA}$ \\
\hline $\mathrm{TKNO}_{3}$ & $3,5 \mathrm{bA}$ & $0,0 \mathrm{aA}$ & $4,5 \mathrm{abA}$ \\
\hline $\mathrm{TH}_{2} \mathrm{SO}_{4}$ & 48,0 aA & $0,0 \mathrm{aB}$ & $1,5 \mathrm{abB}$ \\
\hline $\mathrm{KNO}_{3} 2 \% 12 \mathrm{~h}$ & $7,0 \mathrm{bA}$ & 7,0 aA & $15,3 \mathrm{aA}$ \\
\hline $\mathrm{KNO}_{3} 2 \% 24 \mathrm{~h}$ & $13,0 \mathrm{bA}$ & 12,0 aA & $11,0 \mathrm{abA}$ \\
\hline $\mathrm{KNO}_{3} 4 \% 12 \mathrm{~h}$ & $13,8 \mathrm{bA}$ & 3,0 aA & $16,5 \mathrm{aA}$ \\
\hline $\mathrm{KNO}_{3} 4 \% 24 \mathrm{~h}$ & $7,0 \mathrm{bA}$ & $1,0 \mathrm{aA}$ & $9,3 \mathrm{abA}$ \\
\hline $\mathrm{KNO}_{3} 6 \% 12 \mathrm{~h}$ & $5,5 \mathrm{bA}$ & 5,0 aA & $5,5 \mathrm{abA}$ \\
\hline $\mathrm{KNO}_{3} 6 \% 24 \mathrm{~h}$ & $13,8 \mathrm{bA}$ & $1,0 \mathrm{aB}$ & $7,5 \mathrm{abAB}$ \\
\hline $\mathrm{KNO}_{3} 8 \% 12 \mathrm{~h}$ & $7,0 \mathrm{bA}$ & $2,5 \mathrm{aA}$ & $1,0 \mathrm{abA}$ \\
\hline $\mathrm{KNO}_{3} 8 \% 24 \mathrm{~h}$ & $7,0 \mathrm{bA}$ & $1,5 \mathrm{aA}$ & $7,0 \mathrm{abA}$ \\
\hline MS & & $211,64^{* *}$ & \\
\hline CV (\%) & & 73,28 & \\
\hline
\end{tabular}

ST: control without treatment; $\mathrm{T} \mathrm{KNO}_{3}$ : control of moistening of the substrate with $\mathrm{KNO}_{3}(0.2 \%) ; \mathrm{T} \mathrm{H}_{2} \mathrm{SO}_{4}$ : control with scarification by $\mathrm{H}_{2} \mathrm{SO}_{4}$.

Means followed by the same lowercase letter in a column and uppercase in a row for each parameter do not differ statistically from each other by the Tukey test $(P>0.05)$.

Data transformed by arcsine $(x / 100)^{1 / 2}$ and the original means are presented.

MS: Mean square; CV: Coefficient of variation; ${ }^{*}$, ${ }^{* *}$ : indicate significant difference by the $\mathrm{F}$ test $(P \leq 0.05$ and $P \leq 0.01$, respectively).

A significant interaction of the lot with the treatments was observed for dead and dormant seeds (Table 7). Overcoming dormancy by the three lots in all treatments was superior to that of the control without treatment. The high percentage of dormant seeds from the untreated controls has been recurrent in several $U$. humidicola studies (Costa et al., 2011; Libório et al., 2017, 2018). $\mathrm{KNO}_{3}$ immersion treatments were efficient for all lots regardless of the dormancy rate.

Variation was observed for the dead seeds between the most efficient treatments for each lot. However, the least harmful treatments for all lots were the control with moistening the substrate with $\mathrm{KNO}_{3}$ and the treatments with $12 \mathrm{~h}$ of immersion of the seeds in $\mathrm{KNO}_{3}$ at $2 \%, 4 \%$, and $6 \%$. The ideal immersion period of the seeds in $\mathrm{KNO}_{3}$ limits the entry of ions into cells, preventing phytotoxicity (Bonome, Guimarães, Oliveira, Andrade, \& Cabral, 2006).

In lots 2 and 3 , the control with $\mathrm{H}_{2} \mathrm{SO}_{4}$ caused the highest seed mortality, with an increase of $43 \%$ and $86 \%$, respectively, compared to the control without treatment. These data corroborated those obtained in the first stage of this research (Table 4), and that 
of other studies that pointed out that the use of $\mathrm{H}_{2} \mathrm{SO}_{4}$ could be harmful to the physiological quality of the seeds (Macedo, Groth, \& Lago, 1994; C. C. Martins \& Silva, 1998; Moreira, 2014).

\section{Table 7}

Dormant seeds (D) and dead seeds (M) of Urochloa humidicola Comum as a function of the lots and treatments applied in the second stage of the research

\begin{tabular}{ccccccc} 
& \multicolumn{3}{c}{$\begin{array}{c}\text { Dormancy } \\
\text { Treatments }\end{array}$} & \multicolumn{3}{c}{$\begin{array}{c}\text { Deads } \\
\text { (\%) }\end{array}$} \\
\cline { 2 - 7 } LT & $30,3 \mathrm{bA}$ & $38,0 \mathrm{bAB}$ & $51,8 \mathrm{cB}$ & $37,8 \mathrm{abB}$ & $37,5 \mathrm{abcB}$ & $19,3 \mathrm{abA}$ \\
$\mathrm{T} \mathrm{KNO}_{3}$ & $1,0 \mathrm{aA}$ & $6,0 \mathrm{aB}$ & $6,0 \mathrm{bB}$ & $24,8 \mathrm{abB}$ & $26,0 \mathrm{aB}$ & $14,0 \mathrm{aA}$ \\
$\mathrm{T} \mathrm{H}_{2} \mathrm{SO}_{4}$ & $3,5 \mathrm{aA}$ & $4,0 \mathrm{aA}$ & $3,0 \mathrm{abA}$ & $31,5 \mathrm{abA}$ & $53,5 \mathrm{cB}$ & $36,0 \mathrm{cA}$ \\
$\mathrm{KNO}_{3} 2 \% 12 \mathrm{~h}$ & $3,0 \mathrm{aA}$ & $7,5 \mathrm{aA}$ & $9,5 \mathrm{bA}$ & $27,0 \mathrm{abA}$ & $29,8 \mathrm{abA}$ & $23,5 \mathrm{abcA}$ \\
$\mathrm{KNO}_{3} 2 \% 24 \mathrm{~h}$ & $3,0 \mathrm{aA}$ & $12,0 \mathrm{aB}$ & $2,0 \mathrm{abA}$ & $25,5 \mathrm{abA}$ & $34,0 \mathrm{abA}$ & $27,5 \mathrm{bcA}$ \\
$\mathrm{KNO}_{3} 4 \% 12 \mathrm{~h}$ & $4,0 \mathrm{aA}$ & $5,0 \mathrm{aA}$ & $5,5 \mathrm{bA}$ & $24,3 \mathrm{abAB}$ & $35,5 \mathrm{abB}$ & $20,0 \mathrm{abA}$ \\
$\mathrm{KNO}_{3} 4 \% 24 \mathrm{~h}$ & $1,0 \mathrm{aA}$ & $7,0 \mathrm{aB}$ & $1,5 \mathrm{abAB}$ & $24,0 \mathrm{aA}$ & $32,0 \mathrm{abA}$ & $32,0 \mathrm{bcA}$ \\
$\mathrm{KNO}_{3} 6 \% 12 \mathrm{~h}$ & $4,0 \mathrm{aA}$ & $3,5 \mathrm{aA}$ & $5,5 \mathrm{bA}$ & $31,0 \mathrm{abB}$ & $32,3 \mathrm{abB}$ & $18,3 \mathrm{abA}$ \\
$\mathrm{KNO}_{3} 6 \% 24 \mathrm{~h}$ & $1,0 \mathrm{aA}$ & $2,0 \mathrm{aA}$ & $0,0 \mathrm{aA}$ & $32,0 \mathrm{abAB}$ & $42,8 \mathrm{bcB}$ & $29,8 \mathrm{bcA}$ \\
$\mathrm{KNO}_{3} 8 \% 12 \mathrm{~h}$ & $2,5 \mathrm{aA}$ & $3,5 \mathrm{aA}$ & $1,5 \mathrm{abA}$ & $29,5 \mathrm{abA}$ & $32,5 \mathrm{abA}$ & $27,8 \mathrm{bcA}$ \\
$\mathrm{KNO}_{3} 8 \% 24 \mathrm{~h}$ & $3,0 \mathrm{aA}$ & $2,5 \mathrm{aA}$ & $1,0 \mathrm{abA}$ & $40,3 \mathrm{bB}$ & $44,8 \mathrm{bcB}$ & $28,8 \mathrm{bcA}$ \\
$\mathrm{MS}$ & & $58,17^{* *}$ & & & $39,34^{*}$ & \\
$\mathrm{CV}(\%)$ & & 43,90 & & & 12,79 &
\end{tabular}

ST: control without treatment; $\mathrm{T} \mathrm{KNO}_{3}$ : control of moistening of the substrate with $\mathrm{KNO}_{3}(0.2 \%)$; $\mathrm{T} \mathrm{H}_{2} \mathrm{SO}_{4}$ : control with scarification by $\mathrm{H}_{2} \mathrm{SO}_{4}$.

Means followed by the same lowercase letter in a column and uppercase in a row for each parameter do not differ statistically from each other by the Tukey test $(P>0.05)$.

Data transformed by arcsine $(x / 100)^{1 / 2}$ and the original means are presented.

MS: Mean square; CV: Coefficient of variation; * ${ }^{* *}$ : indicate significant difference by the $\mathrm{F}$ test $(P \leq 0.05$ and $P \leq 0.01$, respectively).

In the comparison of treatments, it was found that the immersion of the seeds in $\mathrm{KNO}_{3}$ solution at all concentrations and periods tested was efficient. However, only at concentrations of $4 \%, 6 \%$, and $8 \%$ for $12 \mathrm{~h}$ and $2 \%, 4 \%$, and $6 \%$ for $24 \mathrm{~h}$ did the overcoming of dormancy result in a significant increase in germination. All of these treatments were subjected to the application by companies. However, to adjust the work routine and reduce costs, the recommended treatment is $4 \%$ for $24 \mathrm{~h}$.

\section{Conclusion}

The immersion in the $\mathrm{KNO}_{3}$ solution was efficient to overcome dormancy and promote germination. To be used by forage producers, the immersion of seeds in $\mathrm{KNO}_{3}$ 2 and $4 \%$ solution for $24 \mathrm{~h}$ are the most suitable treatments to overcome dormancy and promote the germination of $U$. humidicola Comum seeds. 


\section{Acknowledgments}

This work was conducted with the support of the Coordination for the Improvement of Higher Education Personnel Brazil (CAPES) - Financing Code 001.

\section{References}

Alves, A. M., Spósito, T. H. N., Martins, F. B., Pinto, L. E .V., Bavaresco, L. G., Soldá, R. B.,... Teixeira, W. F. (2017). Superação de dormência em Brachiaria humidicola com ácido sulfúrico em diferentes estágios de armazenamento. Colloquium Agrariae, 13(Esp.), 196-202. doi: 10.5747/ca.2017. v13.nesp. 000193

Araújo, R. F., Zonta, J. B., Araújo, E. F., Heberle, E., \& Zonta, F. M. G. (2011) Teste de condutividade elétrica para sementes de feijão-mungo-verde. Revista Brasileira de Sementes, 33(1), 123-130. doi: 10. 1590/ S0101-31222011000100014

Barbosa, J. C., \& Maldonado, W., Jr. (2015). AgroEstat - Sistema para análises estatísticas de ensaios agronômicos. Jaboticabal, SP: FUNEP.

Betoni, R., Scalon, S.P. Q., \& Mussury, R. M. (2011). Salinidade e temperatura na germinação e vigor de sementes de mutambo (Guazuma ulmifolia LAM.) (Sterculiaceae). Revista Arvore, 35(1), 605-616. doi: 10.1590/ s0100-67622011000400004

Binotti, F. F. S., Sueda, C. I., Jr., Cardoso, E. D., Haga, K. I., \& Nogueira, D. C. (2014). Tratamentos pré-germinativos em sementes de Brachiaria. Revista Brasileira de Ciências Ágrarias, 9(4), 614-618. doi: 10.5039/agraria.v9i4a2781
Bonome, L. T. S., Guimarães, R. M., Oliveira, J. A., Andrade, V. C., \& Cabral, P. S. (2006). Efeito do condicionamento osmótico em sementes de Brachiaria brizantha cv. Marandu. Ciência e Agrotecnologia, 30(3), 422-428. doi: 10.1590/S1413-7054 2006000300006

Ministério da Agricultura, Pecuária e Abastecimento (2009). Regras para Análise de Sementes. Brasília, DF: Mapa/ ACS: Brasília.

Cardoso, E. D., Sá, M. E., Haga, K. I., Binotti, F. F. S., \& Costa, E. (2015). Qualidade fisiológica e composição química de sementes de Brachiaria brizantha em função do condicionamento osmótico. Revista de Agricultura Neotropical, 2(2), 42-48. doi: 10.32404/rean.v2i2.264

Carvalho, D. B., \& Carvalho, R. I. N. (2009). Qualidade fisiológica de sementes de guanxuma em influência do envelhecimento acelerado e da luz. Acta Scientiarum Agronomy, 31(3), 489-494. doi: $10.4025 /$ actasciagron.v31i3.585

Carvalho, N. M., \& Nakagawa, J. (2012). Sementes: Ciência, tecnologia e produção. Jaboticabal, SP: FUNEP.

Costa, C. J., Araújo, R. B., \& Villas Bôas, H. D. C. (2011). Tratamentos para a superação de dormência em sementes de Brachiaria humidicola (Rendle) schweick. Pesquisa Agropecuária Tropical, 41(4), 519-524. doi: 10.5216/pat.v41i4.15100

Dias, N. S., Blanco, F. F., Souza, E. R., Ferreira, J. F., Sousa, O. N., Neto, \& Queiroz, Í. S. R. (2016). Efeitos dos sais na planta e tolerância das culturas à salinidade. In Manejo da salinidade na agricultura: estudos básicos e aplicados pp. 151-162. Fortaleza, CE: 
Instituto Nacional de Ciência e Tecnologia em Salinidade.

Euclides, V. P. B., Valle, C. B., Macedo, M. C. M., Almeida, R. G., Montagner, D. B., \& Barbosa, R. A. (2010). Brazilian scientific progress in pasture research during the first decade of XXI century. Revista Brasileira de Zootecnia, 39(Suppl. Spe.), 151-168. doi: 10.1590/s1516-35982010001300018

Gazola, D., Zucareli, C., \& Camargo, M. C. (2014). Comportamento germinativo de sementes de cultivares de milho sob condições de hipoxia. Científica, 42(3), 224-232. doi: 10.15361/1984-5529.2014v42n3 p224-232

Libório, C. B., Verzignassi, J. R., Fernandes, C. D., \& Lima, N. D. (2018). Superação da dormência em sementes de Brachiaria humidicola cv. BRS Tupi pelo uso de ácido giberélico. Revista de Ciências Agrárias, 61(18), 1-9. doi: 10.22491/rca.2018.2601

Libório, C. B., Verzignassi, J. R., Fernandes, C. D., Valle, C. B., Lima, N. D., \& Monteiro, L. C. (2017). Potassium nitrate on overcoming dormancy in Brachiaria humidicola 'BRS Tupi' seeds. Ciência Rural, 47(6), 1-8. doi: 10.1590/0103-8478cr20160500

Lopes, J. C., \& Macedo, C. M. P. (2008). Germinação de sementes de couve chinesa sob influência do teor de água, substrato e estresse salino. Revista Brasileira de Sementes, 30(3), 79-85. doi: 10.1590/S0101-31222008000300011

Macedo, E. C., Groth, D., \& Lago, A. A. (1994). Efeito de escarificação com ácido sulfúrico na germinação de sementes de Brachiaria humidicola (Rendle) Schweick. Pesquisa Agropecuária Brasileira, 29(2), 455-460. doi: 10.1590/S0101-312220070 00200020
Marcos, J., Fo. (2015). Fisiologia de sementes de plantas cultivadas. Londrina, PR: ABRATES.

Martins, C. C., \& Silva, W. R. (1998). Superação da dormência de sementes de capim colonião. Planta Daninha, 16(2), 77-84. doi: 10.1590/s0100-83581998000200001

Martins, C. C., Velini, E. D., \& Martins, D. (1997). Superação da dormência de sementes de capim-carrapicho. Planta Daninha, 15(1), 61-71. doi: 10.1590/S0100-83581997000 100008

Martins, L., \&Silva, W. R. (2001). Comportamento da dormência em sementes de braquiária submetidas a tratamentos térmicos e químicos. Pesquisa Agropecuária Brasileira, 36(7), 997-1003. doi: 10.1590/ so 100-204X2001000700010

Melo, L. F., Martins, C. C., Silva, G. Z., Boneti, J. E. B., \& Vieira, R. D. (2016). Beneficiamento na qualidade física e fisiológica de sementes de capim-mombaça. Revista Ciência Agronômica, 47(4), 667-674. doi: 10.5935/1806-6690.20160080

Mendonça, G. S., Martins, C. C., Martins, D., \& Lopes, M. T. G. (2015). Aspectos físicos e fisiológicos de sementes de Fimbristylis dicothoma relacionados à germinação e dormência. Revista Ciência Agronômica, 46(3), 539-545. doi: 10.5935/1806-6690. 20150036

Moreira, D. A. L. (2014). Superação da dormência em sementes de Brachiaria humidicola cv. BRS Tupi durante o armazenamento. Dissertação de mestrado, Universidade Estadual Paulista, Faculdade de Ciências Agronômicas, Botucatu, SP, Brasil.

Oliveira, G. M., Matias, J. R., Silva, P. P., Ribeiro, R. C., \& Dantas, B. F. (2014). Germinação 
de sementes de Aroeira-do-sertão (Myracrodruon urundeuva Fr. All) e Mororó (Bauhinia cheilantha (Bong) Stend.) em diferentes condutividades elétricas. Revista Sodebras, 9(104), 70-73.

Schossler, T. R., Machado, D. M., Zuffo, A. M., Andrade, F. R., \& Piauilino, A. C. (2012). Salinidade: efeitos na fisiologia e na nutrição mineral de plantas. Enciclopédia Biosfera, 8(15), 1563-1578.

Silva, G. Z., Martins, C. C., Cruz, J. O., Jeromini, T. S., \& Bruno, R. L. A. (2017). Evaluation the physiological quality of Brachiaria brizantha cv. BRS "Piatã" seed. Bioscience Journal, 33(3), 572-580. doi: 10.14393/ BJ-v33n3-36519

Steiner, F., Oliveira, S. S. C., Martins, C. C., \& Cruz, S. J. S. (2011). Comparação entre métodos para a avaliação do vigor de lotes de sementes de triticale. Ciência Rural, 41(2), 200-204. doi: 10.1590/s010384782011005000011
Tomaz, C. D. A., Martins, C. C., Silva, G. Z., \& Vieira, R. D. (2016). Period of time taken by Brachiaria humidicola (Rendle) Scheweick seed to complete germination. Semina:Ciências Agrárias, 37(2), 693-700. doi: 10.5433/1679-0359.2016v37n2p693

Torres, F. E., Anderson, J. P., Teodoro, P. E., Ribeiro, L. P., Corrêa, C. G., \& Silva, F. A. (2016). Eficiência de tratamentos químicos e térmico na quebra de dormência de três espécies de Brachiaria. Revista de Ciências Agrárias, 39(2), 210-215. doi: 10.19084/rca15094

Verzignassi, J. R., Silva, J. I., Fernandes, C. D., Jesus, L., Corado, H. S., Libório, C. B.,... Putrick, T. C. (2013). Ácido sulfúrico na superação de dormência em sementes de Brachiaria humidicolaBRS Tupi. Congresso Brasileiro de Sementes. Florianópolis, SC, Brasil. 